\title{
Os judeus e a questão judaica nas obras de F. M. Dostoiévski
}

\section{Jews and the Jewish Question in the Work of F. M. Dostoevsky}

Autor: Liev Semiónivitch Vygótski Tradutor: Priscila Nascimento Marques Edição: RUS Vol. 12. № 158 Data: Abril de 2021 


\section{Os judeus e a questão judaica nas obras de F. M. Dostoiévski}

\section{Liev Semiónivitch Vygótski Tradução de Priscila Nascimento Marques*}

Resumo: 0 texto foi escrito na juventude pelo conhecido psicólogo soviético L. S. Vygótski. A despeito da pouca idade do autor, o ensaio apresenta um exame agudo de uma questão candente da história da literatura russa - a relação problemática com a figura do judeu. Após um panorama das representações judaicas em diferentes autores (Púchkin. Gógol e Lérmontov, por exemplo), Vygótski se detém na presença polêmica e controversa do jid na obra dostoievskiana.

\begin{abstract}
The text was written by the well-known Soviet psychologist L. S. Vygosky in his youth years. Despite the young age, the essay presents an acute exam of a burning question in Russian literature: the problematic attitude towards Jews. After presenting an overview of the portrayal of Jews by different authors (such as Pushkin, Gogol, Lermontov), Vygotsky examines the polemic and controversial presence of the zhid in the work of Dostoevsky.
\end{abstract}

Palavras-chave: F. M. Dostoiévski; L. S. Vygótski; Questão judaica; Crítica literária Keywords: F. M. Dostoevsky; L. S. Vygotsky; Jewish question; Literary criticism 
Nota introdutória

* Professora de russo da Faculdade de Letras da Universidade Federal do Rio de Janeiro. Mestra e doutora pelo Programa de Pós-Graduação em Literatura e Cultura Russa da Faculdade de Filosofia Letras e Ciências Humanas da Universidade de São Paulo. Realizou estágio de pós-doutorado no mesmo programa com período BEPE na Freie Universität Berlin. E-mail: priscilamarques@letras.ufrj.br, https://orcid.org/0000-0002-71116372

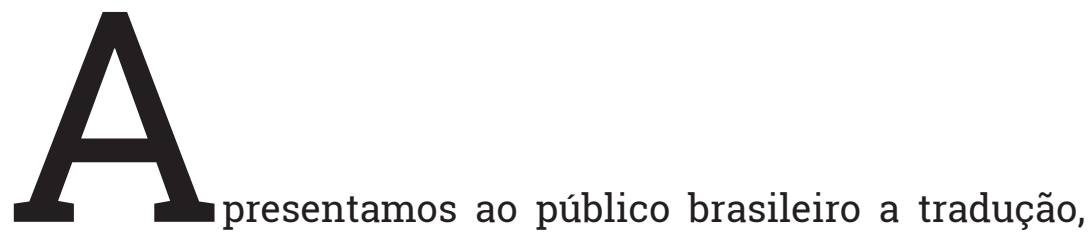
inédita em português, do texto de Liev Semiónovitch Vygótski "Os judeus e a questão judaica nas obras de Dostoiévski". O manuscrito inacabado não chegou a ser publicado, e só veio à luz em 2000, como apêndice ao livro Ot Gomelia do Mosky: Natchalo tvórtcheskogo put Lva Vygótskogo, organizado por I. M. Feigenberg e publicado em 2000. Estima-se que o texto foi escrito entre 1912 e 1913, ou seja, ainda nos anos de colégio.

Trata-se de uma obra rara, pouco conhecida entre os estudiosos de Vygótski, e que revela tanto a precocidade do autor quanto a posição de destaque ocupada pela temática judaica entre seus interesses de juventude. Semión Dóbkin, amigo de Vygótski, relata que este era profundamente interessado pelo tema da história do povo judaico, a tal ponto que organizou um círculo de estudos do qual participou o próprio Dóbkin, sua irmã Fánia e a irmã de Vygótski, Zinaída. O círculo fundado pelo jovem Vygótski, aos 15 anos de idade, existiu durante aproximadamente dois anos e centrava-se, segundo Dóbkin, "não tanto no estudo da história judaica, quanto à filosofia da história. A história pragmática pouco interessava Liev Semiónovitch. Penso que ela interessava pouco aos seus ouvintes. As questões $O$ que é a história?, O que é uma nação?, O que torna as pessoas uma nação? eram-nos mais interessantes."1

Ainda sobre a "questão judaica", para além do manuscrito sobre Dostoiévski, Vygótski escreveu para o periódico judaico Novi Put entre 1916 e 1917 crônicas e resenhas literárias (sobre o romance Petersburgo, de Andrei Biéli e sobre a obra de Mikhail Lérmontov - ao tratar deste último, aliás, o autor recupera muito do argumento apresentado no presente manuscrito). Nessa categoria podem ser listados ainda os textos sobre o

1 Dóbkin, S. "Liev Vygótski v moikh vozpominániia". In: Feigenberg, I. Ot Gomelia do Mosky: Natchalo tvórtcheskogo put Lva Vygótskogo, Lewinston: Edwin Mellen Press, 2000, p. 8. 
teatro em língua ídiche, que Vygótski assistiu e resenhou para o jornal local Nach Ponediélnik, em 1922.

A importância do tema judaico na obra inicial de Vygótski já foi apontada por alguns pesquisadores, ${ }^{2}$ embora ainda seja uma descoberta relativamente recente da vygotskoviédenie. Seu profundo interesse pela literatura e as artes, por outro lado, é mais difundido e conhecido, uma vez que suas primeiras obras - o estudo sobre a tragédia shakespeariana Hamet e o livro Psicologia da arte, produzidos em 1915 e 1925, respectivamente - foram editadas, traduzidas e têm figurado como objeto de estudo por especialistas da teoria histórico-cultural, ainda que não seja, diga-se, uma temática prioritária deste campo.

Na primeira parte do manuscrito, cuja tradução é apresentada a seguir, Vygótski passa em revista as representações estereotipadas e sem profundidade da figura do judeu na literatura russa. $\mathrm{O}$ autor se dedica a examinar diferentes autores e identifica os lugares-comuns, os clichês aplainadores e, em geral, pejorativos, que acompanham a representação do jid. Interessante notar que até um recorte de gênero se faz presente nessa leitura crítica. Por fim, a primeira parte oferece um levantamento do tratamento dessa figura especificamente na obra dostoievskiana, preparando o terreno para uma reflexão mais aprofundada, que será realizada na segunda parte.

Na segunda parte, Vygótski debate as respostas de Dostoiévski sobre seu alegado antissemitismo, particularmente a partir do texto "A questão judaica", publicado em março de 1877 no Diário de um escritor. O jovem Liév Semiónivitch escancara as contradições e aponta até certo cinismo nos argumentos mal-ajambrados do romancista para desviar de tão terrível acusação. Por fim, Vygótski aponta para uma surpreendente redenção para Dostoiévski. Para ele, há algum substrato de verdade acerca do povo judaico na problemática e aguda visão de Dostoiévski. Essa improvável superação dialética, infelizmente, não é desenvolvida até o fim, já que o manuscrito não chegou a ser concluído.

2 Por exemplo, Kotik-Friedgut (2012), Zavershneva (2012) e Marques (2016). 


\section{Referências bibliográficas}

DÓBKIN, Semión. "Liev Vygótski v moikh vozpominániia". In: Feigenberg, I. M (Org.). Ot Gomelia do Moskvy: Natchalo tvórtcheskogo put Lva Vygótskogo. Lewinston: Edwin Mellen Press, 2000.

ZAVERSHNEVA, E. Iu. "Evreiski vopros v neopublikovannykh rukopisiakh L. S. Vygotskogo". Voprosy psikhologuii, n. 2, pp. 79-99, 2012.

KOTIK-FRIEDGUT, Bella. Germinated seeds: the development of Vygotsky's psychology of art in his early journalistic publications (1916-1923). Education circles, novembro, 2012.

MARQUES, Priscila Nascimento. O teatro judaico na língua ídiche na crítica teatral de L. S. Vygótski. Cadernos De Língua $E$ Literatura Hebraica, (14), 47-62, 2016. https://doi.org/10.11606/ issn.2179-0892.cllh.2016.125030 


\section{Os judeus e a questão judaica nas obras de F. M. Dostoiévski}

O futuro historiador do judaísmo na Rússia, ao estudar as manifestações características do antissemitismo, deter-se-á perplexo, como que diante de um enigma, frente à relação da literatura russa com os judeus. Já Púchkin definiu a relação dos escritores posteriores: "Bateu-me à porta um judeu desprezível" ("Tchiórnaia Chal"). ${ }^{3}$ É estranho e incompreensível: apesar de ter defendido os princípios da humanidade e se desenvolvido sob o signo do humanismo, a literatura russa trouxe tão pouco de humano à representação do jid. ${ }^{4}$ É impossível conciliar a humanidade de Gógol com a representação de Iánkel (Tarás Bulba) e o quadro dos pogroms contra os judeus. E essa atitude de Gógol, isto é, humanidade e humanismo para com todos, exceto por Iánkel, é simbólica em todos os escritores posteriores. Outro fato também causa estranheza: apesar de ter levado o realismo à sua expressão extrema e, pelo caminho da genial revelação psicológica dos mistérios da alma humana, ter ultrapassado o limite em que o real se torna simbólico, a literatura russa trouxe tão pouca profundidade psicológica para a representação dos judeus, de modo que tais imagens espalhadas nas mais geniais criações não respondem às mínimas exigências do realismo artístico.

Começando pelo "romance de costumes" de F. V. Bulgárin, Ivan Vyjiguin (1829), que representa de forma grosseira o jid criminoso, passando por toda a literatura russa (com raríssimas exceções), em toda parte encontramos a mesma relação com os judeus e - o que é ainda mais impressionante e notável - a mesma representação deles. É difícil acreditar, embora páginas das melhores obras da literatura russa sejam provas

3 "0 xale preto", poema de Aleksandr Púchkin escrito em 1820. (N. da T.)

4 Denominação depreciativa para judeu (evrei, em russo). (N. da T.) 
disso, que a representação dos judeus seja a mesma em Bulgárin, Gógol, Turguêniev, Dostoiévski, Púchkin, Nekrássov e outros.

Sempre e em toda parte, seja Iánkel, de Gógol (Tarás Bulba), Hirschel Tropman, de Turguêniev (do conto "Jid"), ou Issái Fomitch Bumchtein de Dostoiévski (Escritos da casa morta), ou, de modo geral, segundo a expressão de A. Gornfeld, o "jid episódico", sem relação direta com a narrativa ou apenas ofendido de passagem, que encontramos com tanta frequência em Gógol, Turguêniev e Dostoiévski, sempre e em toda parte o jid é, na visão do autor, um "judeu desprezível", e do ponto de vista da representação objetiva ele é a personificação dos vícios humanos em geral e dos nacionais em particular.

Se enfileirássemos citações com descrições de jides feitas por Turguêniev, Gógol e Dostoiévski, seria difícil identificar o autor de cada excerto, tão pouco há de individual e próprio na representação da figura do jid.

Os tipos de judeus na literatura russa foram por muito tempo elaborados conforme um lugar-comum, o qual foi criado na mente da população russa de todas as camadas sociais e transferido da vida para a literatura, ecos naturais de noções tradicionais sobre o desconhecido mundo do judaísmo e da relação cotidiana com os jides.

É claro que esse grave pecado da literatura russa (não diante do judaísmo, evidente, mas diante da verdade artística!) não é exclusividade dela. Se quisermos rastrear a origem desse lugar-comum seremos levados às fontes da literatura europeia ocidental. A Idade Média, que determinou a atitude cotidiana para com os judeus e contaminou os séculos com antissemitismo, criou e transferiu para a literatura esse lugar-comum que, até os nossos dias, mantém-se quase inalterado.

Na Idade Média, como atesta Leroy-Beaulieu, ${ }^{5}$ "o judeu tinha de suportar muitas ofensas. Quase sempre era obrigado a fa-

5 Todas as citações foram retiradas do livro Os judeus e o antissemitismo, de Leroy-Beaulieu.

[Henri Jean Baptiste Anatole Leroy-Beaulieu (1842-1921), autor de Les Juifs et l'Antisémitisme, Israël chez les Nations (1893), foi um historiador francês especializado na história da Rússia. (N. da T.) ] 
zer o papel de bobo na Máslenitsa, para o divertimento da gente da rua. O judeu divertia a multidão; servia-lhe de objeto de zombaria. No melhor dos casos, suscitava apenas risos". Eis porque também na literatura "ele de fato se converteu numa espécie de Arlequim que sempre interpreta o mesmo papel". Eis porque "os poetas e beletristas representaram apenas o judeu estereotipado, rastejante, maroto, rapinante". Eis a origem dessa regra antiga, mas que há muito se mantém firme entre os dramaturgos: "Todos sabem - disse Alexandre Dumas que os judeus no palco devem sempre ser engraçados" ("Lettre à M. Cuvillier-Fleury").

É característico observar, a fim de confirmar a posição acima apresentada (isto é, de que na representação do judeu, a literatura peca não diante do judaísmo, mas diante da verdade artística), que com esse lugar-comum do jid perverso e engraçado existia (e continua existindo) um modelo segundo o qual, por um longo período, foram criados tipos de mulheres judias.

"Se o judeu - diz Leroy-Beauleiu - deve suscitar repugnância, a judia, ao contrário, é dotada de todos os meios possíveis de sedução. Todas as judias são atraentes, assim determina a tradição." Essa legítima heroína das baladas foi mantida, infelizmente, não só nas operetas, mas foi também ilegitimamente (de forma artisticamente ilegítima) reestabelecida no drama, em romances, novelas e contos.

"Nosso senso cavalheiresco, ou nossa fragilidade ariana, sempre se submeteu facilmente aos encantos de seus olhos aveludados e cílios longos. No que diz respeito a elas, ao que parece, não existe antissemitismo" - conclui sagazmente Leroy-Beauleiu.

Não obstante, acrescento eu, essas imagens das baladas (atualmente das operetas) são igualmente (se não ainda mais!) ilegítimas artisticamente, e tampouco respondem às mínimas exigências do realismo artístico, como é o caso das imagens dos jides.

A literatura russa também conhece essa imagem da "jovem jidovka", que encontramos não apenas em "Ballada", 6 de Lér-

6 "Balada", poema escrito por Mikhail Lérmontov em 1832. (N. da T.) 
montov, como em romances, dramas e novelas. O próprio Púchkin definira a relação do autor com ela. Essa não é uma jidovka desprezível! Ele diz:

Pela fé em Moisés, amanhã,

Aos beijos teus, sem me acanhar

Pronto estou, judia, a me entregar ${ }^{7}$

Contudo, apesar da boa vontade do autor em relação à judia e seus beijos, ou ao "encanto de seus olhos aveludados e cílios longos", essa imagem é artisticamente tão ilegítima quanto a do judeu que desperta apenas desprezo.

A questão, portanto, não é apenas a relação do autor (e isso é característico, observo entre parênteses, mas é uma questão secundária, como tratarei adiante!), mas a ilegitimidade artística, o lugar-comum, o estereótipo de ambas as imagens.

Assim, se por um lado essa relação habitual com os judeus e esse lugar-comum, esse estereótipo são sempre uma representação idêntica, por outro, como é característico e profundamente impressionante que a literatura russa... não, que a literatura mundial tenha produzido apenas um Shylock! ${ }^{8}$

O mistério do espírito judaico, da psicologia judaica, era e continua sendo um enigma não resolvido, que os decifradores da alma humana em vão tentaram (será que tentaram?) desvendar.

$O$ rosto judaico, marcado por um pesar inquieto e uma aflição incompreendida, que se ocultam bem no fundo do olhar do judeu, não aparece no retrato artístico, mas o característico nariz saliente judaico e a pronúncia esquisita para o ouvido alheio foram apresentados em milhares de caricaturas.

No campo da representação artística de tipos judaicos, Dostoiévski não foi muito mais longe que os outros escritores. Não encontramos em suas obras nenhuma imagem artística dos judeus. "Não há sequer uma imagem artística do judeu em

7 Do poema "Khristos voskres" ("Cristo ressuscita"), escrito por Púchkin em 1821. (N. da T.)

8 Judeu agiota, personagem de 0 mercador de Veneza, de William Shakespeare. (N. da T.) 
Dostoiévski", constata V. Jabotínski ("Russkaia laska"). ${ }^{9}$ Não passam de charges, assim como os judeus de Gógol, que, segundo expressão de A. Gornfeld, aparecem "não como figuras reais, mas caricaturas, que surgem predominantemente para fazer rir ao leitor".

"Na representação de seu camarada de galé Issái Fomitch Bumchtein (Escritos da casa morta, 1861), Dostoiévski não colocou nada além de desprezo infinito", diz A. Gornfeld.

"Judeu desprezível", o eterno estribilho da canção cômica sobre o jid.

Aleksandr Petróvitch Goriántchikov, que conduz a narrativa, assim descreve Issái Fomitch:

"Já não era jovem, andava perto dos cinquenta, de baixa estatura e fraco, astuto e ao mesmo tempo um rematado pateta. Era atrevido e arrogante e a um só tempo covarde ao extremo [...]. Fora preso sob acusação de assassinato. Escondia uma receita que seus amigos jides lhe haviam conseguido de um médico logo depois do patíbulo. Essa receita permitia preparar um unguento, que, depois de umas duas semanas de uso, apagava as marcas [das vergastadas]. Ele não ousava empregá-lo no presídio e esperava concluir a pena de doze anos para, depois, uma vez desterrado para algum povoado, aproveitar-se sem falta de tal receita. 'Senão não vou poder me cassar', disse-me certa vez, 'e quero cassar sem falta'. [...] Estava sempre em magnífico estado de espírito. Para ele, a vida no presídio era fácil; com o ofício de ourives, vivia sobrecarregado de trabalho, que recebia da cidade, onde não havia um ourives, e assim escapava aos trabalhos pesados. Naturalmente, era ao mesmo tempo agiota, e abastecia o presídio inteiro cobrando juros e praticando o penhor." (Capítulo IV - "Primeiras impressões") ${ }^{10}$

9 "O afago russo", artigo publicado em 1909 por Vladímir Jabotínski, pertencente a uma série de artigos ocasionados pelo "protesto" de dois escritores progressistas contra o que estes chamaram de "invasão de escritores judeus nas letras russas". (N. da T.)

10 Citado a partir de: Dostoiévski, F. M. Escritos da casa morta. Tradução de Paulo Bezerra. São Paulo: Editora 34, 2020, pp. 101-2. (N. da T.) 
Mas é claro! É evidente! Não precisa nem dizer! Senão ele não seria judeu! De fato, os termos "judeu" e "usurário" são sinônimos! Com efeito, isso determina o lugar-comum!

E essa é apenas a "primeira impressão". Como vemos, ele é engraçado ("se cassar") e agiota. As duas coisas fazem dele um judeu.

Não surpreende, portanto, que Issái Fomitch fosse amado pelos poloneses:

"Talvez unicamente porque ele os divertia. Aliás, nosso jidezinho também gozava da afeição de outros presos, embora todos, sem exceção, zombassem dele. Era o único jid entre nós, e até hoje não consigo me lembrar dele sem rir. Sempre que o olhava, vinha-me à lembrança o Iánkel, do Tarás Bulba de Gógol, que quando se despe para passar a noite com sua mulher numa espécie de armário, fica no mesmo instante parecidíssimo com um frango. O nosso jidezinho Issái Fomitch e um frango depenado eram tão parecidos como duas gotas d'água." (Capítulo IV) ${ }^{11}$

É simbólico que Issái Fomitch faça o autor dos Escritos da casa morta se lembrar de Iánkel: de fato, ele é tão parecido com o "jidok gogoliano" como "duas gotas d'água" e faz lembrar seu protótipo. Essa semelhança, é claro, não serve à imagem artística de Dostoiévski, uma vez que ela pode ser explicada de forma demasiadamente simples: Issái Fomitch foi criado conforme o modelo do "jidok gogoliano", ou melhor, ambos foram criados por um mesmo modelo que é anterior aos dois. E ambos aparecem com o mesmo objetivo: eles "divertem", e "não conseguimos nos lembrar deles sem rir".

Contudo, não se deve pensar que numa descrição mais detalhada Dostoiévski tenha ido mais longe do que nas "Primeiras impressões". Issái Fomitch aparece apenas nos momentos em que é preciso fazer o leitor rir. Eis como a "engraçadíssima história" de sua chegada é contada: "Chegara ao presidio de forma engraçadíssima [...] Os presidiários o aguardavam com impaciência, e abriram caminho assim que ele apareceu à entrada [...] Ao redor ouviram-se risos e gracejos, voltados para sua origem judaica" (Capítulo IX). ${ }^{12}$

11 Cf. Dostoiévski, 2020, p. 101. (N. da T.)

12 Cf. Dostoiévski, 2020, p. 160. (N. da T.) 
Logo que chegou, Issái Fomitch passou, obviamente, a emprestar dinheiro a juros.

"Não passava necessidade, até vivia à larga [...] emprestava sob penhor e a juros a todo presídio. [...] Trazia em si a mescla mais cômica de ingenuidade, tolice, astúcia, impertinência, simplicidade, timidez, jactância e descaramento [...]. Era evidente que Issái Fomitch servia como objeto de divertimento e da permanente distração de todos." (Capítulo IX, grifo do autor $)^{13}$

Essa também é, evidentemente, a serventia de Issái Fomitch para o autor. "Meu Deus, que tipo divertido e engraçado era aquele homem!", ele exclama.

Vale observar, para ressaltar como o relato sobre Issái Fomitch soa dissonante no livro, o qual é imbuído de um espírito de humanidade elevada e por uma ideia de santidade da pessoa humana, o passatempo do prisioneiro Luká: "Luká, que em toda vida conhecera muitos jides, bulia frequentemente com ele, mas sem nenhuma maldade, só por divertimento, do mesmo jeito que a gente se diverte com um cãozinho, um papagaio, um bichinho adestrado etc"144 (Capítulo IX, grifos meus).

A seguir, uma citação do diálogo de Luká com o jid: "- Cuidado, jid, eu te dou uma sova! [...] - Maldito lazarento! [...] - Jid lazarento!"15 etc. etc. (Capítulo IX).

Dostoiévski ressalta muitas vezes que isso não é "de modo algum por maldade, mas por divertimento", e que Issái Fomitch "não se ofendia o mínimo". ${ }^{16}$

Permito-me contrapor esse divertimento ("sem nenhuma maldade!") com outro, o divertimento do tenente Smiekálov, sobre quem se fala no mesmo livro (Parte II, Capítulo II).

Smiekálov era duramente castigado com piadas e risos, também não por maldade, mas por divertimento, para fazer rir.

13 Cf. Dostoiévski, 2020, p. 159-160. (N. da T.)

14 Dostoiévski, 2020, p. 161. (N. da T.)

15 Dotoiévski, 2020, p. 161. (N. da T.)

16 Dostoiévski, 2020, p. 161. (N. da T.) 
"Numa palavra, uma boa alma! Um galhofeiro!"17 Com piadas "zomba o vergastador, até o vergastado quase chega a zombar". ${ }^{18}$

No entanto, quão diferente é a relação do autor com os dois divertimentos. Quanta dor oculta, que alimenta uma fúria nobre, quanta dor por uma alma humana ultrajada sentimos nas palavras sobre o divertimento de Smiekálov!

O divertimento de Luká "com um cãozinho, um papagaio" é examinado pelo autor com um sorriso, quando de fato a cena, terrível em seu cinismo, é um insulto à alma humana, embora seja uma "história engraçadíssima".

A humanidade e o humanismo se vingam cruelmente pela violação de seus direitos: as palavras "um cãozinho, um papagaio, um bichinho adestrado" lançam uma sombra sobre todas as cenas vivas, escritas com dor pela pessoa humana.

Profundamente notáveis são as palavras do deformado e caricato Iánkel de Gógol (suas únicas palavras vivas): "Pensam, se é judeu [jid], então não é gente". ${ }^{19}$

Esse pipilar abafado da caricatura, por acaso ele não trata do fato de que a humanidade se vinga cruelmente pela violação dos seus direitos quando nos dirigimos a um ser humano como se ele fosse "um cãozinho, um papagaio, um bichinho adestrado"? Com efeito, essa é a mais forte acusação que o caricato Iánkel pode lançar sobre seu torturador, Gógol.

De forma semelhante, nas obras de Dostoiévski encontramos um claro exemplo de vingança da verdade artística.

"Toda sexta-feira à noite os presidiários das outras casernas vinham à nossa a fim de ver Issái Fomitch celebrando o sabá [...]. Com uma imponência pedante e estudada, cobria num canto a sua minúscula mesinha e abria o livro, acendia duas velas e, balbuciando umas palavras misteriosas, envergava sua casula, ou cassula, como ele pronunciava [...] Atava umas

17 Dostoiévski, 2020, p. 241. (N. da T.)

18 Dostoiévski, 2020, p. 241. (N. da T.)

19 GÓGOL, Nikolai. Tarás Bulba. Tradução de Nivaldo dos Santos. São Paulo: Editora 34, 2007, p. 141. (N. da T.) 
pulseiras em ambos os braços e, bem no meio da testa, prendia com uma tira uma caixinha de madeira, de modo que dali parecia brotar um chifre engraçado." (Capítulo IX) ${ }^{20}$

O leitor russo, depois dessa descrição, vai ficar muito impressionado ao descobrir que o judeu nunca usa filactérios (tefilin) à noite ou aos sábados, de modo que era duplamente impossível Issái Fomitch usar "pulseiras e caixinha" à noite, menos ainda na sexta, véspera do sábado, quando, segundo o credo judaico, tem início o sabá.

A seguir, o tefilin é preso não em ambos os braços, como fez o personagem de Dostoiévski, mas apenas no esquerdo; e nele se prendem não "pulseiras", mas aquelas "caixinhas", como a que ele tem na cabeça.

Essa descrição absurda, impossível na realidade (sequer existe tefilin para ambos os braços e cabeça!) da oração de Issái Fomitch é bastante significativa. Ela caracteriza a veracidade artística da imagem de Dostoiévski. Oh, e agora podemos duvidar descrição da oração, quando ele diz que o judeu, ao rezar "entre os mais intensos soluços, começava a gargalhar". ${ }^{21}$

A nêmesis da arte não perdoa a representação do desconhecido: não é possível acreditar no judeu de Dostoiévski, ele é inventado. É preciso observar que o ardoroso interesse de Issái Fomitch pelo espetáculo teatral é considerado por A. Gornfeld seu "único traço não caricato".

Igualmente "proposital", na opinião de A. Gornfeld, é o destaque que Dostoiévski dá a elementos estéticos na imagem de outro judeu, apresentado no romance Os demônios (1871).

Liámchin, pequeno funcionário provinciano dos correios, é um talentoso músico e contador de histórias. Contudo, a semelhança se limita apenas aos "elementos estéticos".

Enquanto Issái Fomitch é um caricatura absurda, saída de um álbum artístico de retratos e cenas contra um pano de fundo geral de charges e caricaturas, o judeu Liamchin não se destaca, e sua origem judaica pode ser considerada absoluta-

20 Dostoiévski, 2020, p. 162. (N. da T.)

21 Dostoiévski, 2020, p. 162. (N. da T.) 
mente fortuita (trata-se de um judeu assimilado, que fala russo corretamente e nada tem do judaísmo, não tem nenhuma relação com ele), não fosse por alguns traços nacionais específicos de caráter que, segundo o lugar-comum, todo judeu deve ter.

O pequeno funcionário dos correios, o "jidok Liámchin", um dos "demônios", participa do assassinato revolucionário, além de ser, é claro, usurário.

Isso é mencionado de passagem e não tem qualquer relação com a ação do romance; a atividade de usurário que ele exerce é fortuita, não está ligada à intriga do romance, não é motivada pelo desenvolvimento do seu caráter.

No mais, Liámchin é um igual entre iguais, um qualquer entre outros quaisquer, um demônio entre demônios, uma caricatura entre outras caricaturas ruins.

Liámchim é um covarde lastimável, um bajulador. Há rumores de que ele teria participado de uma escandalosa profanação do ícone da Mãe de Deus. Liámchin toma parte no assassinato revolucionário de Chátov. Mas ele "não suportou". ${ }^{22}$ Depois de um acesso repugnante de pavor fisiológico e infame covardia, ele delatou os demais e pediu "que fosse necessariamente lembrado com quanta franqueza e polidez ele esclarecia o caso, e que também doravante ele poderia ser útil para prestar serviço às autoridades". ${ }^{23}$

É sempre possível reconhecer um judeu num retrato artístico. Já a uma caricatura só se pode acrescentar um "nariz adunco". Esse "nariz adunco", sinal exterior pelo qual é possível reconhecer o judeu no caricato Liámchim, é sempre acompanhado de seu complemento: jidok. Retire essa palavra e você nunca reconhecerá um judeu naquela figura. Não há necessidade interna em seu judaísmo, ele é desprovido de fundamento real, é absolutamente injustificado interna ou externamente. Seu judaísmo é uma particularidade exterior da caricatura (ainda que não fortemente carregada em Dostoiévski), se tem "nariz adunco", é "jidok"; se é jidok, é usurário.

22 As citações foram retiradas seguinte edição: DOSTOIÉVSKI, F. M. Os demônios. Tradução Paulo Bezerra. São Paulo: Editora 34, 2004, p. 645. (N. da T.)

23 Dostoiévski, 2004, p. 647. (N. da T.) 
A certa altura, Dostoiévski fala dele da seguinte maneira: "o patife realmente tinha talento". ${ }^{24}$

O atributo "patife" aparece em toda parte como complemento a jidok: uma palavra ofensiva, uma alcunha injuriosa, que revela o profundo desprezo do autor pelo sujeito representado, mas que de modo algum indica o pertencimento deste ao povo judeu, o seu judaísmo.

"Nessa época, Dostoiévski não via no judeu nada além de um objeto de desprezo", diz A. Gornfeld.

No Diário de um escritor, encontramos uma valiosa indicação a esse respeito: "A palavra jid, até onde me recordo - reconhece Dostoiévski -, era sempre referida por mim para designar uma certa ideia" (Março de 1877, Capítulo II).

Se os termos jidovismo, reino dos jides e outras são empregados por Dostoiévski para designar uma ideia portadora de um conteúdo inteiramente definido, a palavra jid, por sua vez, serve exclusivamente para designar toda baixeza do herói e sua relação para com ele.

Assim, se revelarmos o sentido da expressão "jid Liámchin", torna-se totalmente compreensível o fato, estranho à primeira vista, de que Liámchin não tem sequer os traços caricatos exteriores de um judeu: e, repito, se retirarmos essa palavra, não será possível reconhecer nele um judeu, e ainda que eu não esteja dizendo que Shylock possa ser reconhecido sem o epíteto "judeu", mesmo Issái Fomitch e Iánkel podem ser reconhecidos sem as explicações correspondentes: eles têm os traços exteriores caricatos de um judeu. Já Liáchin, nem enquanto caricatura é judeu.

A denominação jidok, às vezes substituída pela palavra "patife", é característica da representação dos judeus por Dostoiévski. A ela está ligado o "jid episódico" que encontramos em muitas de suas obras. O caráter desse "jid episódico" é o mesmo que existia na literatura precedente, como, por exemplo, em Turguêniev. Esse jid não tem relação direta com a narrativa, é mencionado de passagem e justamente no sen-

24 Dostoiévski, 2004, p. 317. (N. da T.) 
tido explicitado acima. Ele não toma parte de forma alguma no desenvolvimento da ação; aparece e logo depoi desaparece; surge como um meteoro; geralmente é descrito como parte do ambiente. A ele pode ser atribuído com igual sucesso (e quase sem prejudicar o sentido) o epíteto de "polaquinho", que também aparece em Dostoiévski na forma do polaquinho episódico, por exemplo, em Crime e castigo.

Em Dostoiévski, o "polaquinho" é sempre alguém "infame, adulador, covarde além de arrogante e insolente", diz V. Jabotínski ("Russkaia laska").

Como vemos, é muito próximo do caráter de Liámchin; é uma descoberta brilhante do sentido da palavra "polaquinho" e, se não fosse pela palavra "arrogante", ela abarcaria o conceito de jidok, que também é "necessariamente alguém infame, adulador, covarde além de insolente". Não há melhor e mais completa definição das características de Liámchin. Assim,

em vez do "jidok Liámchin", o "polaquinho Liámchin". O "jidok episódico" e o "polaquinho" coincidem inteiramente entre si.

O jid episódico pode ser encontrado em quase todos os romances de Dostoiévski: em Crime e castigo, Os irmãos Karamázov, $O$ idiota, $O$ adolescente e em muitos contos. Em todos os casos, é claro, aparece com o colorido correspondente, que deve estar totalmente claro depois de ter sido aqui revelado o segredo do termo jid.

Darei alguns exemplos desse "judeu episódico".

Em Crime e castigo (parte VI, capítulo VI), são descritas as peregrinações de Svidrigáilov "em diferentes tabernas e cloacas". Ele estava ligado a dois escrivãezinhos que o divertiam em algum parque de diversões. No parque, os escrivães brigaram. "O mais certo era que - diz Dostoiévski - um deles havia roubado alguma coisa e já conseguira vender ali mesmo a algum jid que aparecera; mas, consumada a venda, não quis dividir o lucro com seu companheiro. Verificou-se que o objeto vendido era uma colher de chá." ${ }^{25}$ 
Em $O$ adolescente, lê-se: "tendo sempre à minha esquerda um almofadinha depravado, acho que um desses jidezinhos". ${ }^{26}$

Ou, no mesmo romance, na descrição do leilão, lê-se: "[...] havia ainda negociantes, jides que cobiçavam os objetos de ouro" ${ }^{27}$ (Parte I, Capítulo II).

Etc., etc... O jid, do jid, para o jid...

Citei ao acaso dois excertos de dois romances, mas se quisesse seria possível continuar com as citações. Em todo caso, a partir dos trechos apresentados já se delineia o caráter do jid episódico e o sentido da palavra jid.

Um sujeito que compra uma colher de chá roubada, um "almofadinha depravado", um trapaceiro nas cartas; um sujeito que cobiça objetos de ouro; todos esses, segundo a terminologia de Dostoiévski, são designados pela palavra jid. E não nos esqueçamos de que se trata de uma palavra que ele usa para designar certa ideia!

Na conclusão, para contrastar com o que foi dito acima, mas não o refutar, apresento uma cena de Crime e castigo, a única cena artística em que um judeu toma parte. Trata-se do único "jid episódico" vivo em que se pode acreditar. Essa faísca de qualidade artística verdadeira, é claro, de modo algum desmente o que foi dito anteriormente. Ao contrário, ela dá relevo ao caráter pretensioso e não artístico das cenas supracitadas. ${ }^{28}$

O crítico que trata das obras artísticas da literatura e que escolhe como critério de avaliação exclusivamente sua legitimidade estética se vê, às vezes, em uma situação bastante difícil. Ele não pode apresentar provas ou confirmações dos seus julgamentos. É impossível provar que certo quadro não é arte e outro, ao contrário, é extremamente valioso no sentido estético. E eu, é claro, tampouco fui capaz de provar que as imagens dos judeus em Dostoiévski não são artísticas.

26 As citações foram retiradas da seguinte tradução: DOSTOIÉVSKI, F. M. 0 adolescente. Tradução Paulo Bezerra. São Paulo: Editora 34, 2015, p. 300. (N. da T.)

27 Dostoiévski, 2015, p. 51. (N. da T.)

280 fragmento anunciado de Crime e castigo não é incluído no texto. (N. da T.) 
"Ele era, caso seja impossível evitar palavras desagradáveis, um publicista histórico universal, cujos interesses iam além de sua época, cujo apelo era direcionado aos séculos e aos povos, cujo olhar mirava a eternidade", diz Vassili Rózanov sobre Dostoiévski (F. M. Dostoiévski. Ensaio crítico biográfico).

"Sua profunda publicística - diz o crítico Iuri Aikhenvald sobre Dostoiévski - era sub specie aeternitatis."

E - coisa estranha! - em suas obras artísticas, ao representar os judeus, o artista genial estava sujeito aos "interesses da sua época"; o "publicista histórico universal" fala da questão judaica em suas obras jornalísticas de tal maneira que fica claro que seus interesses iam além de sua época. Ao examinar a questão judaica, seu "apelo é direcionado aos séculos e aos povos, seu olhar para a eternidade". Ele analisou a questão judaica sub specie aeternitatis.

Nisso reside o que há de novo e profundo nas palavras ditas por Dostoiévski sobre essa complexa questão. Examinemos tais palavras.

"Há algum tempo", Dostoiévski passou a receber cartas de judeus (agora sabe-se que os correspondentes judeus citados por Dostoiévski são A. Kovner, T. V. Lurie e Sara Lurie), nas quais os correspondentes o repreendiam duramente por atacar os jides. "Eu pretendia tocar num tema que decididamente não sou capaz de explicar para mim mesmo - escreve um desses correspondentes a Dostoiévski. - Trata-se de seu ódio pelos jides, que se revela em quase todos os números do seu Diário de um escritor."

É preciso dizer que em todos as oportunidades que teve Dostoiévski atacou os judeus: jid, jidichki, jidki, ${ }^{29}$ jidístas, jidificar são palavras que quase não saem das páginas do Diário de um escritor. "Todas essas insinuações e indicações salpicadas aqui e ali no Diário criaram forte impressão no leitor judeu e fizeram com que alguns resolvessem iniciar uma correspondência com o autor" (A. Gornfeld). Em resposta à reprimenda,

29 Esta e a anterior são formas do diminutivo. (N. da T.) 
Dostoiévski escreveu um artigo sobre a questão judaica, publicado no Diário de um escritor em março de 1877 (Capítulos II e III). ${ }^{30}$

Nesse artigo, com seu típico "páthos doentio de convicção" (A. Gornfeld) Dostoiévski primeiramente responde à reprimenda e ao ataque, tocando de passagem em muitos aspectos ligados a um exame mais detalhado da questão judaica e, ao mesmo tempo, emite alguns julgamentos sobre a questão judaica sub specie aeternitatis.

"Oh, não pensem que eu realmente pretendo levantar a 'questão judaica' - ele inicia o artigo. - Escolhi esse título de brincadeira. [O título do artigo é "A 'questão judaica", que ele apresenta entre aspas.] Levantar uma questão tão grandiosa está além de minhas forças." Antes de tudo, Dostoiévski quer isentar-se da recriminação de odiar o povo judeu. "O que é ainda mais surpreendente: como e por que estou sendo visto como alguém que odeia os judeus como povo, como nação? Uma vez que semelhante ódio nunca existiu em meu coração, eu desde já e antes de qualquer palavra rejeito tal acusação que pesa sobre mim de uma vez por todas."

Isso é importante, é valioso. Mas será assim? Gostaria de dizer: será que Dostoiévski não se enganou (não admitiremos que tenha sido insincero intencionalmente) quanto à sua relação com os judeus, não teria ele confundido seu desejo consciente de não odiar com a ausência de ódio? Penso que seja exatamente esse o caso.

"Será que me acusam - ele diz - de odiar os judeus pelo fato de eu, às vezes, referir-me a eles por jid? Bem, em primeiro lugar, eu não pensava que fosse tão ofensivo; em segundo lugar, até onde me lembro, cito o termo jid sempre para designar uma determinada ideia: jid, jidismo, reino jid etc. Com isso é designado certo conceito, certa tendência, uma característica da época. É possível discutir sobre essa ideia, discordar dela, mas não se ofender com a palavra." ("A questão judaica")

É claro que não é apenas no emprego do termo jid que o ódio de Dostoiévski aos judeus se manifesta. Contudo, mesmo aí é

30 Farei referência a esse artigo abaixo, indicando apenas o nome de suas partes. 
como se ele mesmo não o refutasse. Em primeiro lugar, não é apenas às vezes que ele se refere aos judeus como jid, como ele diz, mas, ao contrário, às vezes, em raríssimas ocasiões (principalmente nesse mesmo artigo, em que ele tenta se isentar da acusação de ódio, mas mesmo nele o termo é encontrado com frequência), ele substitui o termo jid por judeu. Em segundo lugar, ele diz: "não pensava que fosse tão ofensivo". Como compreender essa afirmação? Será que ele quer dizer que ele sabe que é ofensivo, mas não imaginava que o fosse em tal grau; ou será que ele absolutamente não imaginava que fosse ofensivo? Quanto ao primeiro caso, é difícil dizer sobre o grau de ofensividade, trata-se de uma questão subjetiva (aliás, o próprio Dostoiévski sabe que "é difícil encontrar algo mais irritante e pedante do que um judeu educado"), mas pretendo mostrar adiante que essa opinião é precisamente "tão" ofensiva. Quanto ao segundo caso, é preciso dizer que essas palavras são clara e conscientemente insinceras. Na realidade, quando Dostoiévski emprega a palavra jid para designar uma ideia, não se deve, em sua opinião, "ofender-se com a palavra", no entanto ela designa uma ideia bastante específica. Não determinarei aqui em que consiste essa ideia, que, em seus traços gerais, é clara a todos; se a alguém (a um indivíduo isolado ou a um povo) for atribuída a ideia de jid ou se seu nome próprio for designado com essa ideia, essa pessoa terá motivos para ficar ofendida, inclusive para ficar "tão" ofendida. Em segundo lugar - e isso é importante - Dostoiévski emprega a palavra jid para designar uma ideia, "até onde se lembra", mas quantas vezes, que sequer se lembra, ele a empregou para designar pessoas específicas, investindo o termo de ódio e desprezo ranzinza; com frequência (oh, com muita frequência!) ele empregou essa palavra inofensiva, como indiquei acima, não para indicar uma pessoa de origem judaica, mas como injúria (por exemplo, sua observação sobre os canalhas, "certamente jides"), amiúde substituindo-a, por sua vez, pelo termo "patife" (Liámchim)!

E não há dúvidas de que, se um nome próprio (de um povo ou de uma pessoa específica) for usado nesse sentido, haverá motivos para se ficar ofendido e mesmo "tão" ofendido. "Seu 
desprezo em relação ao povo jid, que 'não pensa em nada além de si mesmo' etc. etc., é bastante evidente", escreve-lhe uma moça judia. E não importa o quanto ele se insurja "contra essa evidência", o quanto ele conteste o próprio fato, seu desprezo em relação aos judeus é evidente.

Ah, Dostoiévski sabe que na relação entre os dois povos russo e judeu - há pouco de consolador para ambos! "Eu apenas gostaria de indicar - ele diz - que a culpa da nossa separação em relação aos judeus pode não ser apenas do povo russo, mas que os motivos podem ter sido acumulados por ambas as partes, e ainda não se sabe de qual delas em maior grau."

Isso tudo é assim, mas gostaria primeiramente de destacar as palavras: "não se sabe de qual delas em maior grau" (adiante, no calor da discussão, Dostoiévski vai longe em outro sentido e afirma que os culpados são quase que exclusivamente os judeus); em segundo lugar, é impossível tirar daí qualquer conclusão quanto à igualdade de direitos (Dostoiévski o faz).

O capítulo seguinte é intitulado "Pro et contra", mas nele Dostoiévski apresenta apenas, fundamentalmente, argumentos contra.

Em primeiro lugar, e esse é o principal argumento de Dostoiévski, "não há em todo mundo outro povo que se lamente tanto de seu destino, constantemente, a cada passo e palavra, de sua humilhação, de seu sofrimento, de seu martírio". Contudo, "eles imperam na Europa, governam-na por meio da Bolsa de Valores" etc. Por isso, Dostoiévski, "não pode acreditar inteiramente nos clamores dos judeus sobre como são oprimidos, torturados e humilhados". "Em minha opinião - ele diz -, o mujique russo, o homem simples russo em geral, carrega um peso até maior do que os judeus."

O correspondente de Dostoiévski insiste em que "antes de tudo, é preciso conceder-lhes [aos judeus] todos os direitos civis". "Pense - ele diz- que eles até hoje estão desprovidos do direito mais fundamental: da livre escolha de domicílio, o que traz uma série de terríveis constrangimentos para toda a massa judaica." 
"Mas pense, senhor correspondente, pense só que enquanto os judeus sofriam com a livre escolha de domicílio, vinte e três milhões das 'massas trabalhadoras russas' aguentavam a condição de servidão; o que obviamente é um pouco mais duro do que não ter direito a 'escolha domiciliar'. E os judeus tinham pena deles? Acho que não; o senhor pode saber detalhes a esse respeito no extremo ocidente da Rússia e no Sul. Não, mesmo naquela época eles clamavam por direitos que nem sequer o povo russo possuía, clamavam e se lamentavam de serem oprimidos e martirizados, e de que quando recebem mais direitos, 'pedem-nos o cumprimento de deveres em relação ao Estado e à população nativa'. E quando chegou o Libertador e libertou o povo nativo, quem foi o primeiro a se lançar contra ele como se fosse uma vítima, quem se aproveitou principalmente de seus vícios, quem o enganou com seu eterno ofício dourado, quem agora substitui, onde foi capaz e ousou, os proprietários eliminados, com a diferença que os proprietários, ainda que fossem grandes exploradores de pessoas, se esforçavam para não arruinar seus camponeses, mesmo que por proveito próprio, isto é, para não exaurir a força de trabalho, já os judeus não se importam com a exaustão da força russa, ele toma o que é seu e parte."

E como prova, Dostoiévski apresenta duas notícias que havia lido: uma do Mensageiro da Europa, segundo a qual os judeus na América "já se lançaram contra uma massa de milhões de negros libertos e já se apropriaram deles com seu conhecido e eterno 'ofício dourado', se aproveitando da inexperiência e dos vícios da 'tribo explorada"; a segunda, uma correspondência de Kaunas, retirada do Novo Tempo, sobre o fato de que os judeus "se lançaram contra a população lituana local" etc.

Oh, Dostoiévski, é claro, não apresenta essas duas notícias como "dois fatos decisivos e capitais". E ainda,

"Se começarmos a escrever a história dessa tribo mundial, imediatamente encontraremos cem mil [excusez du peu!] fatos como esses e ainda mais significativos; de modo que que um ou dois fatos não acrescentam nada de mais; contudo, há algo de curioso: se num debate ou num momento de reflexão 
pessoal o senhor precisar de uma referência sobre os judeus e seus feitos, não vá até uma biblioteca, não revolva livros antigos ou suas próprias anotações velhas, não tenha trabalho, não procure, não se esforce, não é necessário nem sair do lugar nem sequer se levantar da cadeira, basta estender a mão para o primeiro jornal que estiver por perto, qualquer que seja, e procurar na segunda ou terceira página: o senhor necessariamente encontrará algo sobre os judeus e infalivelmente aquilo que é mais característico, sempre a mesma coisa, sempre as mesmas façanhas!" (Advirto aos leitores que porventura possam ceder ao conselho de Dostoévski e estender a mão para pegar o primeiro jornal que encontrarem. Tal experimento hoje em dia é muito perigoso. Oh, é claro, os senhores também "na segunda ou terceira página" encontrarão "aquilo que é mais característico" para a situação dos judeus na Rússia, e "infalivelmente a mesma coisa", mas temo, receio muito, que esse "algo sobre os judeus" será não o "algo" de que fala Dostoiévski e, estou seguro, os senhores encontrarão "algo" exatamente contrário.)

"E isso, os senhores hão de concordar, - continua Dostoiévski - significa alguma coisa, indica alguma coisa, revela alguma coisa, ainda que os senhores sejam completamente ignorantes sobre os quarenta séculos de história dessa tribo. É claro, recebo como resposta que todos estão tomados de ódio e por isso todos mentem. Evidente que é muito possível que seja o caso de todos mentirem, mas aí surge outra questão: se absolutamente todos mentem e estão dominados pelo ódio, esse ódio tem origem em algo, esse ódio generalizado quer dizer algo, 'afinal a palavra todos deve significar algo!', como costumava exclamar Bielínski."

Oh, é claro que quer dizer "algo", mas está longe de ser aquilo que pensava Dostoiévski!

Depois dos trechos supracitados, soa estranha a afirmação categórica de Dostoiévski:

"Talvez eu não tenha conhecimentos sólidos sobre a vida judaica, mas de uma coisa estou certo e discutirei com quem quer que seja: não há entre a nossa gente simples qualquer 
ódio religioso preconcebido e obtuso contra os judeus, do tipo: 'Foi Judas quem traiu Cristo'. Isso pode ser ouvido da criançada ou de bêbados, mas o povo como um todo olha para o judeu, repito, sem qualquer ódio preconcebido. Eu vi isso durante cinquenta anos. Ocorreu-me inclusive de viver com $o$ povo, com uma massa de gente, nas mesmas casernas, dormir nas mesmas tarimbas. Lá havia alguns judeus, e ninguém os desprezava, ninguém os excluía ou os enxotava. Quando eles rezavam (e os judeus rezam aos gritos, com uma vestimenta especial) ninguém considerava estranho, não os atrapalhavam ou riam-se deles, o que, aliás, seria de se esperar daquele povo rude, segundo a nossa concepção, como é o povo russo; ao contrário, ao vê-los, diziam: 'É assim que é a fé deles, é assim que rezam', e passavam por eles com tranquilidade e quase com aprovação. E esses mesmos judeus se esquivavam de muitos russos, não queriam comer com eles, olhavam-nos de cima (e logo onde? - na prisão!) e demonstravam repugnância e asco em relação ao povo russo 'nativo'. O mesmo ocorria nas casernas de soldados e em toda parte na Rússia: procure saber, pergunte se os judeus eram ofendidos como judeus, como $j i$ des, pela fé, pelos costumes. Em parte alguma eram ofendidos e o mesmo vale para todo o povo. Ao contrário, asseguro-lhes que, nas casernas ou em qualquer parte, o povo simples enxerga e compreende muito bem (e nem os judeus o ocultam) que os judeus não querem comer com ele, têm aversão a ele, evitam-no e se protegem dele o quanto podem, e ao invés de se ofender com isso, o povo russo simples diz clara e calmamente: 'É assim a fé dele, por causa da fé ele não come e se afasta' (ou seja, não porque é mau), e ao compreender esse motivo superior ele perdoa o judeu com toda a sua alma."

Ao retirar a acusação de ódio ao povo judeu que pesa contra si, Dostoiévski quer retirar a acusação que pesa contra todo o povo russo. Mas será que ele consegue? Penso que não. Ele mesmo mostra o contrário em suas obras. E, como é característico, não apenas os heróis das suas obras literárias, mas ele mesmo não compreende esse "motivo superior", segundo suas próprias palavras, que faz com que os judeus se afastem, e ele mesmo lança a acusação contra os judeus, ainda que diga que 
o povo russo simples compreende o "motivo superior". Dostoiévski não o compreende.

Dostoiévski afirma que na prisão ninguém desprezava os judeus, ninguém ria deles, ninguém considerava estranhas suas orações. Mas temos a prisão das galés de Recordações da casa dos mortos, temos Issái Fomitch Bumchtein, um judeu em meio ao povo "nativo". Como o "povo russo simples" se relaciona com ele? "Riam-se dele decididamente e sem exceção", diz Dostoiévski (capítulo IV). É verdade que, mais adiante (capítulo IX), Dostoiévski diz: "Causava-me muita estranheza que os forçados não rissem dele [o que, devo observar, soa muito esquisito depois da supramencionada afirmação e ainda mais de forma tão categórica], mas apenas zombavam por diversão". Quando ele chega à prisão, "a seu redor ressoaram os risos e as piadas dos prisioneiros sobre sua origem judaica". Oh, depois disso, será possível acreditar quando Dostoiévski afirma que em parte alguma ofendiam "os judeus como judeus, como jides"? E temos o diálogo (o prisioneiro Lutchka com frequência o provocava para fazer graça): "- $\hat{E}$, jid, vou te cobrir de pancadas! - Sarnento maldito! - Jid sarnento! - Traiu Cristo!"

Oh, que chistes encantadores, que diversão inocente! Oh, quando Issái Fomitich rezava, não era "com tranquilidade e quase com aprovação" que os outros o viam, como afirma Dostoiévski no Diário, mas "vinha gente de outras casernas até a nossa apenas para ver Issái Fomitch celebrar o sabá". "É assim que é a fé deles, é assim que rezam", diziam os prisioneiros, segundo as palavras de Dostoiévski no Diário. Já em Recordações da casa dos mortos, quando ouviam a oração de Issái Fomitch, diziam: "Vai se desmontar todo!". E vocês se lembram que no momento da oração de Issái Fomitch o major "arfou de rir e o chamou de idiota"; já no Diário, Dostoiévski afirma que a prece "não era considerada estranha por ninguém".

Ele afirma que "não há entre nossa gente simples qualquer ódio religioso preconcebido e obtuso contra os judeus, do tipo: 'Foi Judas quem traiu Cristo'". Ah, se fosse assim! A literatura russa é prova exatamente do contrário. Vocês se lembram que os personagens do conto "Jid", de Turguêniev, sorriam invo- 
luntariamente enquanto Hirschel era arrastado à forca: seus gritos eram tão engraçados, seus pulos e movimentos corporais eram tão monstruosos. E vocês se lembram do terrível quadro ("Hoje ficaríamos de cabelo em pé - diz Gógol - por aqueles terríveis sinais de crueldade daquele século semisselvagem" $)^{31}$ do pogrom contra os judeus cometido pelos cossacos (Tarás Bulba), quando os cossacos viam apenas "caras deploráveis, deformadas pelo pavor"32 e quando afogavam os jides "vendo os pés dos judeus calçados com botinas e meias se agitando no ar" ${ }^{33}$ Vocês se lembram do quadro cotidiano de Memórias de um caçador ("O fim de Tchertopkhánov") que mostra os camponeses espancando um jid a troco de nada, sem motivos, apenas por ser judeu, porque "crucificou Cristo".

$E$ caso se lembrem disso, duvidarão seriamente das palavras de Dostoiévski. Não me porei a examinar todos os argumentos de Dostoiévski, suas afirmações e principalmente as acusações que levanta contra o povo judeu. Na verdade, seria possível indicar que o isolamento dos judeus tem, segundo as palavras do próprio Dostoiévski, um "motivo elevado", que não é pelo fato de os judeus terem "substituído os proprietários" que eles não devem ter igualdade de direitos, mas, ao contrário, por causa da restrição nos locais de residência. Mas isso tudo são questões particulares, históricas e econômicas, que não podem aqui ser analisadas por uma única pessoa. Mas, além disso, esses são ataques vulgares, um antissemitismo banal. E o leitor pode observar sem dúvida que são afirmações vulgares, e com elas Dostoiévski não disse nada de novo sobre a questão judaica. Interessa apenas do ponto de vista psicológico: isso caracteriza sua atitude para com o povo judeu. Ele afirma não atacar os judeus como nação, como povo (tentei mostrar que isso não é verdade), mas nesse artigo ele os ataca seguidamente como povo. Ele afirma que no coração do povo russo não há ódio, mas, em primeiro lugar, apenas no do povo simples e, em segundo lugar, ele mesmo se refere a esse ódio e

31 Gógol, 2007, p. 62. (N. da T.)

32 Gógol, 2007, p. 55. (N. da T.)

33 Gógol, 2007, p. 56. (N. da T.) 
diz que ele, de fato, quer dizer algo. Não analisarei os argumentos sobre a igualdade de direitos, neles não há nada de original ou novo, mas quero apontar que também esses julgamentos são muito característicos da relação dúbia de Dostoiévski com os judeus.

"Tudo o que exigem a humanidade e a justiça, tudo o que exigem o humanismo e a lei cristã, tudo isso deve ser feito para os judeus", diz Dostoiévski. E adiante:

"Sou firmemente a favor da total ampliação dos direitos dos judeus na legislação formal e, se for possível, da total igualdade de direitos com a população nativa (N.B.: Embora, talvez, em alguns casos eles tenham até mais direitos, ou melhor dizendo, maior possiblidade de usufruir deles, do que a própria população nativa). É claro que me vem à mente uma imagem extravagante: e se de alguma forma e por algum motivo nossa obschina agrícola se abalar, aquela que protege nosso pobre mujique nativo de tanta maldade, e se na direção desse mujique emancipado, tão inexperiente, tão incapaz de se conter diante da tentação e que até então era tutelado pela obschina, afluir uma horda de judeus? Eis o que acontecerá: num piscar de olhos ele se acabará, todos os seus bens, toda sua força passará já no dia seguinte para o poder dos judeus, e terá início um tempo que não poderá ser comparado nem com a época da servidão nem com a dos tártaros." (Diário de um escritor do ano de 1877, Obras completas, Tomo XXI, p. 86)

Assim, se resumirmos os argumentos de Dostoiévski, teremos o seguinte: é preciso dar direitos aos judeus, mas o que será dos camponeses? Repito que isso é interessante apenas do ponto de vista psicológico, uma vez que revela sua duplicidade. Ou então, é preciso analisar os argumentos de um e de outro lado: o correspondente judeu prova que os kulaks russos não são melhores do que os judeus, ao que Dostoiévski retruca: $\operatorname{sim}$, mas os russos não sofreram menos que os judeus. Dostoiévski diz: "Oh, eles gritam que amam o povo russo", não obstante, a partir de suas próprias cartas fica clara também "a obstinação que dá provas claras de como os judeus veem os russos". A questão da relação entre russos e judeus é muito 
complexa e não tínhamos intenção de levantá-la aqui. Em todo caso, Dostoiévski afirma que entre o povo simples não há ódio, e adiante diz que "na camada da intelligentsia ouvem-se vozes a favor dos judeus em mais de uma ocasião". Não analisaremos aqui as invectivas contra o povo judaico por ele não se arrepender de ter "arrendado o povo russo". Eis o que importa, o que é notável: Dostoiévski mesmo considerava, provavelmente, que também sua voz ressoava em favor dos judeus ("Tudo o que exigem a humanidade e a justiça" etc.), contudo, a partir da presente análise, fica claro que muito embora Dostoiévski afirme de forma clara e determinada que em seu coração não há ódio contra o povo judeu, ele se mostra um antissemita que odeia o povo judeu. E essa relação é simbólica para todos os membros da intelligentsia russa, , com raras exceções, ao menos, é claro, no que se refere à sua relação com a questão judaica. Embora Dostoiévski pertencesse à ala conservadora, graças ao que apenas raramente sua duplicidade se manifestava, sua relação dúbia com a questão judaica é simbólica para quase toda a intelligentsia russa. Uma coisa é clara: um sujeito que alcança certo nível intelectual não pode aceitar a ideologia gregária e cega do "antissemitismo cotidiano", ele renuncia ao epíteto de antissemita, ele declara, ele deve declarar que é a favor dos judeus, mas o instinto pequeno burguês é forte; ele, sem reconhecê-lo abertamente, é antissemita. Esse é o caso de Dostoiévski. E isso é, repito, simbólico. Assim, gostaria de observar um traço característico: em seu artigo, Dostoiévski, não obstante, observa:

"Judeus educados, ou seja, aqueles que (conforme minhas observações, mas, advirto de antemão, de maneira alguma estou as generalizando) sempre tentar dar a conhecer que saibam que eles, graças à sua educação, já não partilham dos 'preconceitos' de sua nação, não cumprem os ritos religiosos como os demais pequenos judeus, consideram que isso está abaixo de seu nível de ilustração, e nem sequer acreditam em Deus..."

Observamos como em duas palavras é captado genialmente e delineado artisticamente um tipo, e quem o faz, isto é, Dostoiévski, que não foi capaz de apontar um judeu sequer. Vemos nessas palavras um tipo muito difundido e cotidiano dos anos 
1860 e 1870 . E isso não surpreende: Dostoiévski os via, os encontrava em São Petersburgo, e por isso, conhecendo-os, ele pode escrever. Oh, não se trata de um usurário, nem de um sujeito com vícios, tampouco engraçado como todos os personagens judeus de Dostoiévski, e isso porque esse tipo era um signo para Dostoiévski.

É característico que Dostoiévski afirme, no calor da discussão, sempre o contrário da realidade. Por exemplo, os russos não são absolutamente livres para a escolha do local de residência. "Quanto aos judeus, está claro para todos que os direitos deles de escolha do local de residência tem se ampliado cada vez mais nos últimos vinte anos. Ao menos, eles têm aparecido em lugares na Rússia onde nunca antes eram vistos." E ainda: não é o povo russo que oprime os judeus, mas o contrário, os judeus que oprimem os russos. É muito característico que Dostoiévski tenha precisado recorrer a uma imagem extravagante:

"E se não houvesse três milhões de judeus na Rússia, mas de russos; e os judeus fossem oitenta milhões: em que eles transformariam os russos, com que desdém os tratariam? Será que lhes dariam os mesmos direitos? Será que os permitiriam rezar entre eles livremente? Será que não os tratariam como escravos? Ou pior: será que não lhes esfolariam o couro de uma vez? Não os arruinariam, não os exterminariam definitivamente?" (Diário de um escritor, p. 80)

E mais: Dostoiévski sabe que "o povo russo tem, talvez, uma antipatia para com ele [o povo judeu], especialmente em certos lugares, e até possivelmente uma forte antipatia", mas a culpa de tudo é do próprio judeu, pois o russo não tem ódio, já o judeu odeia o povo simples russo.

Entre os membros da intelligentsia todos são a favor dos judeus, já o judeu educado não se relaciona bem com o russo.

Dostoiévski vai longe demais em suas invectivas. E o principal é sua duplicidade: ao afirmar que não ataca os judeus como povo, ele os ataca precisamente nesse artigo. Vejam só: "O judeu, onde quer que tenha aparecido, humilhou e corrompeu ainda mais fortemente o povo, a humanidade decaiu ainda mais e o nível de educação rebaixou-se ainda mais, a pobreza 
irremediável e inumana se disseminou de maneira ainda mais abjeta, e com ela o desespero" (Diário de um escritor, p. 83).

Mas ainda que ele tenha se equivocado bastante e tenha dito muitas coisas más sobre os judeus, muitas coisas falsas e contraditórias sobre a relação entre os dois povos; ainda que esteja errado em suas conclusões extremas, mas que partem de seu pensamento fundamental, ele disse muitas coisas corretas e profundas. É preciso separar "o joio do trigo" nas palavras de Dostoiévski sobre os judeus, pôr de lado (oh, do ponto de vista psicológico isso tudo é muito curioso) aquilo que é injusto, dito no calor da discussão, examinar o que é novo e profundo e pensar sobre as conclusões a partir disso. Por isso, cito novamente o pensamento principal de Dostoiévski.

"Mas, apenas de toda 'extravagância' e de tudo que escrevi antes, continuo sendo total e decididamente a favor da igualdade de direitos, pois essa é a lei de Cristo, pois esse é o princípio cristão. Mas se é assim, por que razão cobri tantas páginas com palavras? O que desejava expressar se, dessa forma, estou me contradizendo? É justamente por não me contradizer e pelo fato de não ver da parte russa, nativa, nenhum obstáculo para a ampliação dos direitos dos judeus, que afirmo que esses obstáculos estão do lado dos judeus em grau incomparavelmente maior do que do lado dos russos, e se até hoje não foi alcançado aquilo que desejamos do fundo do coração, o povo russo é incomparavelmente menos culpado do que o próprio judeu." (Diário de um escritor, p. 86)

Culpados são os judeus. E ao exclamar "Viva fraternidade", Dostoiévski tem dúvidas sobre "quanto os judeus são aptos a servir à nova e bela causa da verdadeira união fraterna com aqueles de outra fé e sangue". Ele diz "é preciso que ambos os lados confraternizem", ele diz que "é possível confiar no povo russo" e está convencido de que o judeu não é capaz disso. E apesar de seus apelos ("Abrandemos as acusações mútuas, façamos com que desapareçam as habituais exaltações dessas acusações que atrapalham a clara compreensão das coisas" Diário de um escritor, p. 87), ele termina com dúvidas: será que os judeus são capazes? E ao tratar de explicar por que não o 
são, Dostoiévski não apresenta pensamentos vulgares, banais (esses já foram apresentados antes), mas novos, profundos, nos quais ele penetra a fundo na questão judaica.

Continua

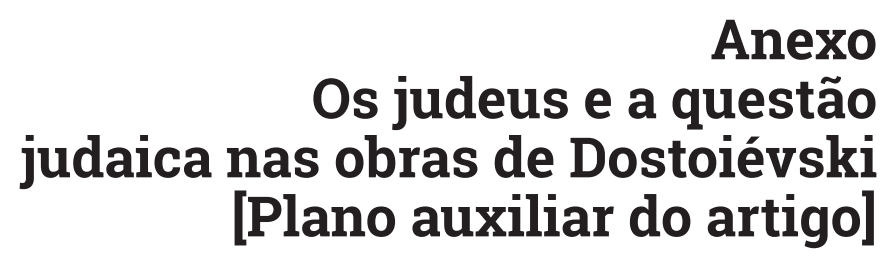

\section{Antissemitismo artístico}

A relação da literatura russa com os judeus; a representação dos judeus pelos escritores russos. "O lugar-comum judaico", sua origem - os judeus na vida e na literatura através dos tempos. Avaliação desse lugar-comum do ponto de vista artístico; um erro comum, previsto por isso / a culpa diante do judaísmo /, seu desmentido, o lugar-comum da mulher judia. - Personagens judeus nas obras literárias de Dostoiévski. Avaliação geral / caráter caricato. - Bumchtein. A atitude do autor para com ele. Traços do "lugar-comum judaico". A ausência de verdade artística em sua representação - / exemplo - ausência inclusive de verdade da vida /. Elementos estéticos. - Liámchin. Judaísmo injustificado. Traços do "lugar-comum judaico". Semelhanças e diferenças com Bumchtein. 0 sentido do seu judaísmo. - O "judeu episódico". Seu caráter na literatura precedente. Comparação com o "polaco episódico". Exemplos e significado geral desse jid. - A cena da morte de 
Svidrigáilov. / Crime e castigo /, avaliação artística do romance; o sentido simbólico do romance; força artística. - A distribuição desigual das forças artísticas na representação dos judeus em Dostoiévski.

\section{Antissemitismo cotidiano}

A base cotidiana do antissemitismo artístico. O "lugar-comum judaico" como produto da criação popular. - $O$ antissemitismo cotidiano de Dostoiévski como base de seu antissemitismo artístico. Opinião geral / fórmula e Gornfeld. /, seus méritos e deficiências. Justificativa de sua definição a priori do antissemitismo de Dostoiévski. Sua correspondência com judeus. Características de seus correspondentes. Seus ataques / fórmula geral /. A objeção de Dostoiévski - a negação de seu antissemitismo. A veracidade de sua negação. $O$ emprego da palavra jid como indicativo de sua relação com os judeus. A ideologia do antissemitismo cotidiano de Dostoiévski.

Recebido em: 17/12/2020

Aceito em: 10/03/2021

Publicado em abril de 2021 